\title{
HUBUNGAN INTENSITAS KEBISINGAN DENGAN KEJADIAN KELUHAN KELELAHAN SUBJEKTIF PADA PEKERJA BAGIAN PRODUKSI DI PKS
}

\author{
Lira Mufti Azzahri ${ }^{1}$, Etri Gustriana ${ }^{2}$ \\ S1 Kesehatan Masyarakat \\ Universitas Pahlawan Tuanku Tambusai \\ Liramuftiazzahri.isnaeni@gmail.com¹,Etri@gmail.com²
}

\begin{abstract}
The use of high-tech machines in the production process will result in the risk of occupational diseases and accidents. Work accidents can be influenced by a work environment that does not comply with standards, including due to noise intensity factors which will result in the risk of work fatigue. The purpose of this study was to determine the relationship between noise intensity and the incidence of work fatigue complaints in production workers at PKS PT.JS. This research is a quantitative analytic study with a cross sectional study design. The sample in this study were all workers in the PKS production section of PT. JS as many as 59 respondents. The variables in this study were noise intensity and subjective complaints of work fatigue. The data analysis used included univariate and bivariate analysis using the chi-square test. The results showed that of the 59 respondents as many as 40 people (67.8\%) experienced non-standard noise intensity, and as many as 41 people (69.5\%) experienced work fatigue. which is high and the statistical test results show that there is a significant relationship between the noise intensity factor and work fatigue complaints, namely ( $p$ value $=0.001)$, To prevent work fatigue, PT. JS should measure and control the work environment, especially in the production section, so that the risk of accidents caused by work fatigue can be anticipated.
\end{abstract}

Keywords

: Fatigue, Noise Intensity, Palm Oil Mill

\begin{abstract}
ABSTRAK
Penggunaan mesin berteknologi tinggi dalam proses produksi akan mengakibatkan timbulnya risiko penyakit akibat kerja maupun kecelakaan kerja. Kecelakaan kerja dapat saja dipngaruhi oleh lingkungan kerja yang tidak sesuai standar diantaranya disebabkan oleh faktor intensitas kebisingan yang akan mengakibatkan timbulnya risiko kelelahan kerja. Tujuan penelitian ini adalah untuk mengetahui hubungan Intensitas kebisingan dengan kejadian keluhan kelelahan kerja pada pekerja bagian produksi di PKS PT.JS. Penelitian ini merupakan penelitian kuantitatif analitik dengan desain cross sectional study. Sampel dalam penelitian ini adalah semua pekerja pada bagian produksi PKS PT. JS sebanyak 59 responden. Variabel dalam penelitian ini adalah intensitas kebisingan, dan keluhan kelelahan kerja subjektif. Analisis data yang digunakan mencakup analisis univariat dan bivariat menggunakan uji chisquare. Hasil penelitian didapatkan bahwa dari 59 responden sebanyak 40 orang $(67,8 \%)$ mengalami Intensitas kebisingan yang tidak standar, dan sebanyak 41 orang $(69,5 \%)$ mengalami kelelahan kerja yang tinggi dan dari hasil uji statistik menunjukkan ada hubungan yang signifikan antara faktor Intensitas kebisingan dengan keluhan kelelahan kerja yaitu dengan ( $p$ value $=0,001)$, Untuk mencegah kelelahan kerja, PT. JS hendaknya melakukan pengukuran dan pengendalian lingkungan kerja khususnya bagian produksi agar risiko kecelakaan yang disebabkan kelelahan kerja dapat diantisipasi.
\end{abstract}

Kata Kunci : Kelalahan, Intensitas Kebisingan, Parbik Kelapa Sawit

\section{PENDAHULUAN}

Globalisasi merupakan salah satu tanda yang menunjukkan bahwa kemajuan dan perkembangan teknologi dan komunikasi mempengaruhi segala aspek, salah satu diantaranya adalah di dunia industri. Banyak industri di Indonesia yang saat ini memanfaatkan perkembangan teknologi dengan tujuan untuk meningkatkan efisiensi 
kerja dan memberikan dampak yang signifikan dalam jumlah produksi. Namun sejalan dengan perkembangan teknologi tersebut terdapat dampak positif dan negatif yang ditimbulkan, dimana salah satu dampak negatif adalah timbulnya faktor fisik berupa polusi di udara dan kebisingan akibat penggunaan mesin (Ramdan,2014)

Upaya kesehatan bagi tiap individu perlu dijaga dan ditingkatkan di manapun individu itu berada, tidak terkecuali di tempat kerja, karena di tempat kerja terdapat berbagai macam faktor penyebab kecelakaan kerja yang diakibatkan oleh kelelahan kerja (Sumakmur, 2014). Kelelahan kerja adalah suatu mekanisme perlindungan tubuh agar tubuh terhindar kerusakan lebih lanjut. Istilah kelelahan biasanya menunjukan kondisi yang berbedabeda dari setiap individu, tetapi semuanya bermuara kepada kehilangan efisiensi dan penurunan kapasitas kerja serta ketahanan tubuh (Tarwaka \& Bakri, 2016)

Tahun 2018 International Labour Organization (ILO) jumlah kasus kecelakaan kerja terus meningkat, tahun 2013 kecelakaan kerja sebanyak 2.102.400, tahun 2014 kecelakaan kerja sebanyak 2.136.000 kasus, dan pada tahun 2015 kecelakaan kerja sangat meningkat sebanyak 2.190.000 kasus. Setiap tahun sebanyak dua juta pekerja meninggal dunia karena kecelakaan kerja yang disebabkan oleh faktor kelelahan. Penelitian tersebut menyatakan dari 58115 sampel, 32,8\% diantaranya atau sekitar 18828 sampel menderita kelelahan. Dari data Badan Penyelenggara Jaminan Sosial (BPJS) Ketenagakerjaan, kasus kecelakaan kerja di Indonesia dari 103.285 kasus kecelakaan kerja di tahun 2015 meningkat mencapai 129.911 kasus kecelakaan kerja di tahun 2016, dan tahun 2017 jumlah kecelakaan kerja sebanyak 105.182 kasus dengan korban meninggal dunia sebanyak 2.375 orang. (Ketenagakerjaan, 2018).

Menurut data Dinas Tenaga Kerja Provinsi Riau tahun 2018 jumlah kasus kecelakaan kerja yaitu 6,768 kasus, sedangkan pada tahun 2019 sebanyak 9.628 kasus kecelakaan kerja (Riau, 2019). Maka dari itu perusahaan menerapkan pentingnya Kesehatan dan Keselamatan Kerja Lingkungan (K3L) diperusahaan. Jenis kecelakaan kerja yang terjadi diperusahaan adalah. Terjatuh, terjepit, tertimpa, yang diakibatkan oleh lingkungan kerja. Gerakangerakan melebihi kemampuan pekerja sehingga pekerja mengalami kelelahan dan menurunnya konsentrasi saat bekerja.

Menurut (Tarwaka \& Bakri, 2016) kelelahan kerja disebabkan oleh dua faktor yakni faktor internal dan eksternal. Faktor internal yang berasal dari indvidu, yaitu: usia, jenis kelamin, status gizi. Faktor eksternal merupakan faktor yang berasal dari luar, yaitu: sikap kerja, beban kerja, tekanan panas, penerangan, kebisingan dan suhu yang berada dilingkungan kerja.

Penelitian yang dilakukan oleh (Kunci, 2020) tentang Hubungan masa kerja, beban kerja, intensitas kebisingan dengan kelelahan kerja di PT Nobelindo Sidoarjo. Menyatakan bahwa masa kerja, beban kerja, intensitas kebisingan dapat mempengaruhi kelelahan kerja. Hal ini terjadi karena semakin buruknya atau semakin tidak sesuai dengan nilai ambang batas (NAB) sebuah lingkungan kerja akan semakin besar resiko terjadinya kelelahan kerja, faktor lingkungan kerja yang diteliti pada penelitian ini adalah faktor kebisingan.

Kebisingan merupakan faktor lingkungan fisik yang berpengaruh pada kesehatan kerja dan merupakan salah satu faktor yang dapat menyebabkan beban tambahan bagi tenaga kerja. Kebisingan adalah bunyi yang tidak dikehendaki karena tidak sesuai dngan konteks ruang dan waktu sehingga dapat menimbulkan gangguan terhadap kenyamanan dan kesehatan manusia (Arini \& Dwiyanti, 2017). Pekerjaan yang dapat mengakibatkan kelelahan kerja yang disebabkan oleh intensitas kebisingan yang tinggi umunya terdapat dipabrik/industri seperti pabrik testil, pabrik kelapa sawit dan pabrik karet, dan lain sebagainya. Intensitas kebisingan mempunyai pengaruh terhadap tenaga kerja dapat mengakibatkan kelelahan berupa: 
Kelelahan otot, yang menyebabkan pekerja merasakan pusing, kantuk, sakit, dan kelelahan (Anizar, 2011)

PT. JS merupakan salah satu perusahaan yang bergerak dibidang perkebunan dan pabrik kelapa sawit. Pengolahan kelapa sawit (PKS) PT. JS memproses buah segar menjadi CPO. Dari data angka kecelakaan kerja di PKS PT.JS tahun 2017 jumlah kasus kecelakaan kerja yaitu 9 kasus, sedangkan pada tahun 2018 sebanyak 11 kasus kecelakaan kerja, dan pada tahun 2019 sebanyak 14 kasus kecelakaan kerja. Berdasarkan survey awal didapati hasil bahwasanya faktor penyebab kecelakaan kerja diperusahaan ini karena kondisi lingkungan kerja yang tidak sesuai standar seperti suara bising yang terdengar di bagian produksi, dimana terdapat banyak mesin besar yang mengluarkan suara yang dapat mengganggu sehingga menimbulkan kelelahan kerja dan menurunya konsentarasi dan efesiensi pekerja yang pada akhirnya dapat meningkatkan risiko kecelakaan kerja.

Penelitian ini bertujuan untuk menganalisis hubungan antara instensitas kebisingan dengan kejadian keluhan kelelahan subjectif pada para pekerja dibagian produksi di pabrik kelapa sawait.

\section{METODE}

Jenis penelitian ini adalah kuantitatif analitik dengan pendekatan cross sectional. Penelitian ini dilakukan di PKS PT. JS pada bulan September 2020 - Januari 2021. Sampel dalam penelitian ini adalah seluruh pekerja di bagian produksi di PKS PT. JS berjumlah 59 orang. Variabel bebas dalam penelitian ini adalah intensitas kebisingan sedangkan variabel terikatnya adalah kelelahan kerja. Alat pengumpulan data yang akan digunakan pada variabel keluhan kelelahan yaitu berupa kuesioner Subjective Self Rating Test (SSRT), sedangkan Intensitas kebisingan pekerja bagian produksi dengan mengukur dengan menggunakan alat Sound level meter pada 5 devisi kerja. Dalam penelitian ini analisa bivariat digunakan untuk menganalisa pengaruh intensitas kebisingan dengan kejadian keluhan kelelahan kerja yakni uji chi square.

\section{HASIL}

\section{Analisis Univariat}

Analisis univariat adalah analisis yang bertujuan untuk mendeskripsikan berbagai karakteristik data penelitian dan distribusi frekuensi dari faktor kebisingan dan faktor beban kerja dengan kejadian kelelahan kerja pada pekerja bagian produksi di PKS PT.JS. Karakteristik Responden

Tabel 1 Distribusi Frekuensi Pekerja Bagian Produksi Berdasarkan Usia di PKS PT.JS.

\begin{tabular}{lll}
\hline Variabel & Jumlah & $\begin{array}{l}\text { Persentase } \\
(\%)\end{array}$ \\
\hline Usia (Tahun) & & \\
\hline $26-35$ & 9 & 15,3 \\
\hline $36-45$ & 30 & 50,8 \\
\hline $46-55$ & 20 & 33,9 \\
\hline Pendidikan Terakhir & & \\
\hline SMA & 32 & 54,2 \\
\hline D3 - S1 & 27 & 45,8 \\
\hline Lama Kerja (Tahun) & & \\
\hline$<5$ Tahun & 27 & 45,8 \\
\hline$\geq 5$ Tahun & 32 & 54,2 \\
\hline Kebisingan & \\
\hline Kebisingan Tidak Standar & 40 & 67,8 \\
\hline Kebisingan Standar & 19 & 32,2 \\
\hline Kelelahan Kerja & & \\
\hline Tinggi & 41 & 69,5 \\
\hline Rendah & 18 & 30,5 \\
\hline Sumber: penyebaran kuesioner &
\end{tabular}

Sumber: penyebaran kuesioner

Pada tabel 1 di dapat dilihat bahwa dari 59 pekerja bagian produksi di PKS PT.JS adalah rentang usianya berada diantara 3645 tahun yaitu sebanyak 30 orang $(50,8 \%)$. Mayoritas pendidikan terakhir responden adalah pendidikan SMA yaitu sebanyak 32 orang $(54,2 \%)$. Lama kerja mayoritas pekerja memiliki lama kerja $\geq 5$ tahun yaitu sebanyak 32 orang (54,2\%). Mayoritas melakukan pekerja pada Kebisingan yang tidak standar yaitu sebanyak 40 orang $(67,8 \%)$. Sebanyak 41 orang $(69,5 \%)$ mengalami kelelahan kerja. 
Analisis Bivariat

Tabel 2 Hubungan Faktor Intensitas kebisingan dengan Kejadian Keluhan Kelelahan Kerja Pada Pekerja Bagian Produksi di PKS PT.JS.

\begin{tabular}{|c|c|c|c|c|c|c|c|c|c|}
\hline \multirow{3}{*}{$\begin{array}{l}\text { Faktor } \\
\text { Kebisingan }\end{array}$} & \multicolumn{4}{|c|}{ Kelelahan Kerja } & \multirow{2}{*}{\multicolumn{2}{|c|}{ Total }} & \multirow{3}{*}{$\begin{array}{l}\text { OR } \\
95 \%)\end{array}$} & \multirow[t]{3}{*}{ (CI } & \multirow{3}{*}{$\begin{array}{l}p \\
\text { value }\end{array}$} \\
\hline & \multicolumn{2}{|c|}{ Tinggi } & \multicolumn{2}{|c|}{ Rendah } & & & & & \\
\hline & $\mathrm{n}$ & $\%$ & $\mathrm{~N}$ & $\%$ & $\mathrm{n}$ & $\%$ & & & \\
\hline Tidak Standar & 34 & 85,0 & 6 & 15,0 & 40 & 100 & 9,71 & & \\
\hline Standar & 7 & 36,8 & 12 & 63,2 & 19 & 100 & $(2,72$ & - & $\cap \Omega 0$ \\
\hline Total & 41 & 69,5 & 18 & 30,5 & 59 & 100 & $34,72)$ & & 001 \\
\hline
\end{tabular}

Keterangan : hasil uji spss

Berdasarkan Tabel 2 dapat diketahui bahwa dari 40 responden yang mengalami kebisingan yang tidak standar saat bekerja, mengalami kelelahan kerja yang tinggi sebanyak 34 orang $(85,0 \%)$. Sedangkan dari 19 responden yang mengalami kebisingan yang standar saat bekerja, mengalami kelelahan kerja yang tinggi sebanyak 7 orang $(36,8 \%)$.

Hasil uji statistik didapatkan $p$ value $=$ 0,001 berarti terdapat hubungan yang signifikan antara faktor kebisingan dengan kejadian kelelahan kerja pada pekerja bagian produksi di PKS PT.JS. Didapat nilai OR 9,71 (95\% CI : 2,72-34,72) artinya dapat disimpulkan bahwa responden yang mengalami kebisingan yang tidak standar pada saat bekerja 9,71 kali berpengaruh mengalami kejadian kelelahan kerja yang tinggi dibandingkan dengan responden yang mengalami kebisingan yang standar pada saat bekerja.

\section{PEMBAHASAN}

\section{Hubungan Faktor Intensitas kebisingan Dengan Keluhan Kelelahan Kerja Pada Pekerja Bagian Produksi di PKS Di PKS PT.JS}

Berdasarkan hasil penelitian dapat diketahui bahwa dari 40 responden yang mengalami Intensitas kebisingan yang tidak standar saat bekerja, mengalami kelelahan kerja yang tinggi sebanyak 34 orang $(85,0 \%)$. Sedangkan dari 19 responden yang mengalami Intensitas kebisingan yang standar saat bekerja, mengalami kelelahan kerja yang tinggi sebanyak 7 orang $(36,8 \%)$.
Hasil uji statistik didapatkan $p$ value $=$ 0,001 berarti terdapat hubungan yang signifikan antara faktor Intensitas kebisingan dengan kejadian kelelahan kerja pada pekerja bagian produksi di PKS PT.JS. Didapat nilai OR 9,71 (95\% CI : 2,72-34,72) artinya dapat disimpulkan bahwa responden yang mengalami Intensitas kebisingan yang tidak standar pada saat bekerja 9,71 kali berpengaruh mengalami kejadian kelelahan kerja yang tinggi dibandingkan dengan responden yang mengalami Intensitas kebisingan yang standar pada saat bekerja.

Hal ini sejalan dengan penelitian yang dilakukan oleh (Johan Amir, Ida Wahyuni, 2019) tentang pengaruh intensitas kebisingan terhadap kelelahan yang mengatakan bahwa intensitas penerangan yang kurang baik dapat mempengaruhi kelelahan pada pekerja sehingga dapat menurunkan angka produktivitas kerja. Penelitian ini juga sejalan dengan penelitian (Laziardy, 2017) "Kebisingan Terhadap Kelelahan Kerja Pada Pekerja Logam Bagian Produksi", didapatkan ada hubungan yang signifikan antara faktor kebisingan dengan kelelahan kerja, pengaruh kebisingan terhdap kelelahan kerja sebesar $14 \%$, sehingga apabila ada kenaikan bising sebesar 1 dBA makan akan meningkatkan kelelahan sebesar 11,477 kali lebih tinggi.

Intensitas kebisingan merupakan faktor lingkungan fisik yang berpengaruh pada kesehatan kerja dan merupakan salah satu faktor yang dapat menyebabkan beban tambahan bagi tenaga kerja(Ihsan \& Siti Salami, 2015). Intensitas kebisingan adalah semua suara yang ada disemua area industri. Pekerjaan yang dapat mengakibatkan 
kelelahan kerja yang disebabkan oleh Intensitas kebisingan yang tinggi umunya terdapat dipabrik/industri seperti pabrik testil, pabrik kelapa sawit dan pabrik karet, dan lain sebagainya. Pencahayaaan mempunyai pengaruh terhadap tenaga kerja diantaranya orang yang rentan terpapar Intensitas kebisingan yang tnggi akan mengakibatkan kelelahan berupa: Kelelahan otot, yang menyebabkan pekerja merasakan pusing, kantuk, sakit, dan kelelahan mata (Anizar, 2011).

Intensitas kebisingan dapat menyebabkan rasa terganggunya konsentrasi pada pekerja dan pskologis para pekerja (Fanny, 2015)(Lira Mufti Azzahri, 2019). Dalam lingkup tenaga kerja, kelelahan kerja merupakan masalah bagi kesehatan tenaga kerja yang berpotensi meningkatkan resiko kecelakaan kerja yang akan menimbulkan banyak kerugian meteri, dan mampu menurunkan produktivitas secara keseluruhan akibat faktor pekerjaan (Widiastuti, 2011)

Kelelahan dibagi atas dua jenis, yaitu kelelahan otot merupakan tremor pada otot atau perasaan nyeri pada otot dan kelelahan umum merupakan kelelahan yang ditandai dengan berkurangnya kemauan untuk bekerja yang disebabkan oleh pekerjaan yang sifatnya statis atau monoton, intensitas dan lamanya kerja fisik, keadaan lingkungan, kondisi mental dan psikologis, status kesehatan dan gizi (Tarwaka \& Bakri, 2016)

Menurut asumsi peneliti pada responden yang mengalami Intensitas kebisingan standar tetapi masih mengalami keluhan kelelahan kerja hal ini dapat disebabkan oleh usia dan lama masa bekerja pekerja tersebut. Pada usia yang tua dapat meningkatkan kelelahan kerja dan kondisi kerja yang berulang-ulang atau monoton yang selalu dilakukan pekerja dalam bertahun lamanya, dapat menyebabkan rasa bosan, serta menjadikan karyawan merasa lelah dan jenuh (Lestari \& Isnaeni, 2020). Namun dapat juga dikarenakan oleh keadaan lingkungan seperti iklim kerja panas(Odi et al., 2018). Seorang tenaga kerja akan bekerja dengan efisien dan produktif bila lingkungan tempat kerjanya nyaman, atau dapat dikatakan efisiensi kerja optimal dalam daerah nikmat kerja, tidak panas dan tidak dingin (Wahyuni \& Indriyani, 2019).

\section{KESIMPULAN}

Hasil penelitian yang dilakukan mengenai hubungan Intensitas kebisingan dengan kejadian keluhan kelelahan kerja subjektif pada pekerja bagian produksi di PKS PT.JS disimpulkan bahwa faktor kebisingan mengakibatkan para pekerja yang bekerja di bagian produksi mengalami kelelahan kerja, sehingga perlunya pihak perusahaan melakukan pengendalian terkait adanya ketidak sesuaian lingkungan kerja yakni faktor kebisingan.

\section{UCAPAN TERIMAKASIH}

Ucapan terima kasih terutama ditujukan kepada LPPM dan pihak Universitas Pahlawan Tuanku Tambusai. Ucapan terima kasih juga kepada perusahaan dan responden yang membantu pelaksanaan penelitian.

\section{DAFTAR PUSTAKA}

Anizar. (2011). Teknik Keselamatan dan Kesehatan Kerja di Industri. Graham Ilmu.

Arini, S. Y., \& Dwiyanti, E. (2017). ANAIISIS FAKTOR YANG BERHUBUNGAN DENGAN TERJADINYA KELELAHAN KERJA PADA PENGUMPUI TOL DI PERUSAHAAN PENGEMBANG JALAN TOL SURABAYA. The Indonesian Journal of Occupational Safety and Health, 4(2), 113. https://doi.org/10.20473/ijosh.v4i2.20 15.113-122

Fanny, N. (2015). Analisis Pengaruh Kebisingan Terhadap Tingkat Konsentrasi Kerja Pada Tenaga Kerja di Bagian Proses PT Iskandar Indah Printing Textile Surakarta. APIKES 
Citra Medika Surakarta, 5(1), 52-61. http://www.apikescm.ac.id/ejurnalinfo kes/index.php/infokes/article/downloa $\mathrm{d} / 85 / 85$

Ihsan, T., \& Siti Salami, I. R. (2015). Hubungan Antara Bahaya Fisik Lingkungan Kerja Dan Beban Kerja Dengan Tingkat Kelelahan Pada Pekerja Di Divisi Stamping Pt. X Indonesia. Jurnal Dampak, 12(1), 10. https://doi.org/10.25077/dampak.12.1. 10-16.2015

Johan Amir, Ida Wahyuni, E. (2019). Hubungan Kebisingan, Kelelahan Kerja Dan Beban Kerja Mental Terhadap Stres Kerja Pada Pekerja Bagian Body Rangka Pt. X. Jurnal Kesehatan Masyarakat (e-Journal), 7(1), 345-350.

Ketenagakerjaan, B. (2018). Laporan Kecelakaan.

Kunci, K. (2020). Hubungan antara Masa Kerja , Beban Kerja , Intensitas Kebisingan dengan Kelelahan Kerja di PT Nobelindo Sidoarjo.

Laziardy, M. (2017). Kebisingan Terhadap Kelelahan Kerja Pada Pekerja Logam Bagian Produksi. Higeia Journal of Public Health Research and Development, 1(2), 84-94.

Lestari, R. R., \& Isnaeni, L. M. A. (2020). Hubungan umur dan status gizi dengan kelelahan kerja pada bidan di rsia bunda anisah tahun 2019. Doppler Universitas Pahlawan Tuanku Tambusai, 4(1), 38-42.

Lira Mufti Azzahri, R. I. (2019). FAKTORFAKTOR YANG BERHUBUNGAN DENGAN KELUHAN PENDENGARAN PADA PEKERJA DIBAGIAN PRODUKSI DI PT. HERVENIA KAMPAR LESTARI. PREPOTIF Jurnal Kesehatan
Masyarakat, 3(2), 9-22.

Odi, K. D., Purimahua, S. L., \& Ruliati, L. P. (2018). Hubungan Sikap Kerja, Pencahayaan Dan Suhu Terhadap Kelelahan Kerja Dan Kelelahan Mata Pada Penjahit Di Kampung Solor Kupang 2017. Ikesma, 14(1), 65. https://doi.org/10.19184/ikesma.v14i1. 10408

Riau, D. T. K. P. (2019). Laporan Kecelakaan.

Sumakmur, P. . (2014). Higiene Perusahaan dan Kesehatan Kerja. Sagung Seto.

Tarwaka, \& Bakri, S. H. A. (2016). Ergonomi untuk Keselamatan, Kesehatan Kerja dan Produktivitas. http://shadibakri.uniba.ac.id/wpcontent/uploads/2016/03/BukuErgonomi.pdf

Wahyuni, D., \& Indriyani, I. (2019). FAKTOR-FAKTOR YANG BERHUBUNGAN DENGAN KELELAHAN KERJA PADA PEKERJA BAGIAN PRODUKSI DI PT. ANTAM Tbk. UBPP LOGAM MULIA. Jurnal Ilmiah Kesehatan, 11(1), 73-79. https://doi.org/10.37012/jik.v11i1.70

Widiastuti, R. (2011). Studi Ergonomi Kognitif Untuk Mengetahui Penurunan Produktivitas Kerja Akibat Kenaikan Tingkat Kebisingan. Jurnal Teknologi, 4(2), 136-145. https://ejournal.akprind.ac.id/index.ph p/jurtek/article/view/899\%0Ahttps://d oc-0o-b8-

docs.googleusercontent.com/docs/secu resc/6g5hu03v4ko8tiaonsd29vpfb6ejb 65p/3hscs1c1rkd443p7nnj1d1fh7ac89 nd4/1584541425000/02562715786992 438959/09415519597562923966/0B3 veF_ 